\title{
New data on the distribution of butterflies (Lepidoptera: Hesperioidea et Papilionoidea) of the Kara river basin arctic tundra (Polar Urals)
}

\author{
Новые данные о распространении булавоусых чешуекрылых \\ арктической тундры в бассейне реки Кара (Помярный Урах)
}

\author{
D.V. Morgun \\ A.B. Моргун
}

Moscow Centre of Environmental Education, Regional Research and Tourism, Odesskaya str., 12A, Moscow 117303, Russia. E-mail:
d_moth@mail.ru
Московский центр экологии, краеведения и туризма, ул. Одесская, 12A, 117303 Москва, Россия.

KEY WORDS. Butterflies (Lepidoptera: Hesperioidea \& Papilionoidea), arctic tundra, biodiversity, Kara river, Polar Urals.

КЛЮЧЕВЫЕ СЛОВА. Булавоусые чешуекрылые (Lepidoptera: Hesperioidea et Papilionoidea), арктическая тундра, биоразнообразие, река Кара, Полярный Урал.

ABSTRACT. The data on the distribution in the Kara river basin of the extreme north eastern Europe (Russian Federation, Nenetsky Autonomous Okrug and Komi Republic) of 24 butterfly species is presented. The concrete localities of butterfly species are mentioned with the geographical coordinates, their biotopical confideness is described, the relative quantity of species is estimated. The species diversity and its possible change are analyzed. Leptidea morsei (Fenton in Butler, 1881) is stated for the whole territory of the Polar and Subpolar Urals for the first time.

РЕЗЮМЕ. В статье представлены данные о распространении на крайнем северо-востоке Европы в бассейне реки Кары (Российская Федерация, Ненецкий автономный округ, Республика Коми) 24 видов булавоусых чешуекрылых. Приводятся указания на конкретные местонахождения видов с данными географических координат, описана их биотопическая приуроченность, оценено относительное обилие видов, проанализировано видовое разнообразие и возможные тенденции его изменения. Для Полярного и Приполярного Урала также впервые приводится Leptidea morsei (Fenton in Butler, 1881).

\section{Introduction}

In the last decades the butterfly fauna (Lepidoptera: Hesperioidea et Papilionoidea) of the Polar Urals and the Bolshezemelskaya tundra is actively studied by different researchers, and the greatest contribution to the study of this insect group in this territory belongs to A.G. Tatarinov, M.M. Dolgin, O.I. Kulakova. Due to the regular research activities, as well as a number of additions with the new taxa descriptions generally 127 species are known from the territory of European NorthEast. 124 species are included in the work of A.G. Tatarinov and M.M. Dolgin [2001], and two endemic taxa (Erebia zaitsevi Nikolaev, 2005, E. callias churki$n i$ Bogdanov, 2008) are described directly from the Polar Urals in recent years. Leptidea morsei (Fenton in Butler, 1881) should also be noted as a new species for the region, for the first time mentioned here for the Polar Urals based on expedition materials in 2017. Earlier in the North-East of Europe it was found only in plain south and middle taiga forests in several localities in Komi Republic (Syktyvkar, Ukhta) [Sedykh, 1974; Tatarinov, Dolgin, 1999, 2001]. In the Polar Urals it was met by O.V. Zurilina $12 \mathrm{~km}$ North of the village of Kharp in the valley of the Sob river (Yamalo-Nenetsky Autonomous Okrug), and also noted in the western foothills of the Subpolar Urals in the area of the Lemva river (Komi Republic) in July 2017.

Despite the fairly good knowledge of the European North-East fauna and regular entomological expeditions in the region, the extreme Northern areas, located on the North-East of Europe are poorly studied. They are located mostly in the basin of Kara river, on the coast of the Kara sea, north of the Polar Urals foothills and differ by the development of the arctic tundra landscapes. Lack of entomologists knowledge of the territory can be explained due to its poor accessibility, lack of settlements and extreme climatic conditions. However, the first special studies of the butterflies of this region were also the first in the entire European North-East and belonged to N.Ya. Kuznetsov [1925], based on the materials of the Russian geographical society expeditions that described the presence of the Oriental and American zoogeographic elements in its fauna. Subsequent literature data on the butterflies based 
solely on this work [Tatarinov, Dolgin, 1999, 2001, etc], and a special field studies were usually conducted by entomologists $100-150 \mathrm{~km}$ to the South, in the mountains of the Polar Urals, as a rule, nearly Vorkuta, and Polar Ural - Sob' - Kharp line. Thus, numerous faunistic works of K.F. Sedykh, Yu.P. Korshunov, P.Yu. Gorbunov, and other authors, as well as the recent expeditions of A. G. Tatarinov, O.I. Kulakova, A. Belik, B.A. Khramov, G.A. Grigoryev, M.G. Nigmatulin, V.O. Zurilina, A. Okulov and the author of this article were conducted in these areas. Many of this expeditions and investigations have contributed to the greatest faunistic works of the last years [Korshunov, Gorbunov, 1995; Korshunov, 2002; Lvovsky, Morgun, 2007].

The results of extensive lepidopterological research of the Bolshezemelskaya tundra reflected in the work of A.G. Tatarinov and O.I. Kulakova [2005], where 61 butterfly species are presented for this area. However, the area north of the lower reaches of the Khalmer-yu river was not covered by them in the forwarding works [Tatarinov, Kulakov, 2007]. In 2017 they publish a new review on the butterflies of the area of the Kara upper flow which contains 43 species. They researched butterflies in 2007 and 2010 in four districts in the Kara basin (the Volchy, Gnetyyu tributaries, the North-Western part of the Ochenyrd range and Verkhnekarsky canyon).

\section{Material and methods}

Our observations cover some new localities in the Kara river basin. In 2015 and 2017 the field collections of Lepidoptera were initiated by us in the area of the Kara basin by the expeditionary groups that held some water touristic routes in this river and its tributaries. The first expedition under the direction of A.V. Makarov and T.V. Aryasova was held 9-22 July 2015, when weather conditions allowed to collect about 50 adult butterflies during five days. In the process of the expedition the collectings were carried out on the coast of Kara and its tributaries (Verhnekarsky canyon, the mouth of the stream Izyachor, Lyadkhey-Yakha, Silova-Yakha). In 2017, the second expedition under the leadership of Prof. I. A. Savinov and S. V. Rupasov were organized and included the research of butterflies and provided about 500 imago specimens. The route of the expedition took place from the mouth of the river Lyadkhey-Yakha and Nyarma-Yakha, next to the river's mouth, Nerusawey-Yaha, the river Brusyyaha to the river Silova-Yakha from 19 to 30 July 2017. The high productivity of this expedition is explained by the stable sunny and warm weather, due to which monitoring was conducted for 8 days, and some days (for example, 22 July 2017) were good for collecting imagines from 8.20 AM to $7.20 \mathrm{PM}$, that is rarely possible for arctic expeditions.

Thus, our studies are held 90 years later the first years of studying Lepidoptera in the Kara basin, according to the available sources. Nearly a century gap in the research gives us an opportunity to analyze trends in faunistic changes.
Butterflies were collected on the linear route, and the geographical coordinates were taken in the collection sites, the position in the landscape of the biotope and its description were fixed, as well as weather conditions.

The Kara river flows along the border of the Nenetsky and Yamalo-Nenetsky Autonomous districts and Komi Republic. The river is formed in North-Western slopes of the Polar Urals at the confluence of the rivers Bolshaya Kara and Malaya Kara. It flows mainly in a northwestern direction along the Pai-Khoi ridge. The material was collected in the following geographical locations which numbers are used in the annotated list as the designation of the butterfly localities:

1. near the mouth of the river Lyadkhey-Yakha, $68.363383^{\circ} \mathrm{N}$, $65.426282^{\circ} \mathrm{E}$ (2017); Lyadkhey-Yakha, $68.214902^{\circ} \mathrm{N}$, $65.261254^{\circ} \mathrm{E}$ and $68.29930^{\circ} \mathrm{N}, 65.234638^{\circ} \mathrm{E}(2015)$.

2. mouth of the river Nyarma-Yakha, from $68.556545^{\circ} \mathrm{N}$, $65.670613^{\circ} \mathrm{E}$ to $68.556545^{\circ} \mathrm{N}, 65.670642^{\circ} \mathrm{E}$;

3. Nyarma-Yakha river valley, right bank, on the route from $68.565354^{\circ} \mathrm{N}, 65.826012^{\circ} \mathrm{E}$ to $68.565354^{\circ} \mathrm{N}, 65$. $826080^{\circ} \mathrm{E}$;

4. Kara river valley, right Bank, near the mouth of the river Nerusawey-Yaha, $68.691841^{\circ} \mathrm{N}, 65.422887^{\circ} \mathrm{E}$;

5. Kara river valley, near the mouth of Brusyyakha river, $68.813862^{\circ} \mathrm{N}, 65.338293^{\circ} \mathrm{E}$;

6. Kara river valley, near the mouth of Silova-Yakha river, $68.839981^{\circ} \mathrm{N}, 64.986431^{\circ} \mathrm{E}(2017)$;

7. mouth of the Silova-Yakha river, $68.502718^{\circ} \mathrm{N}, 65$. $231548^{\circ} \mathrm{E}(2015)$;

8. Verhnekarsky canyon, $67.554614^{\circ} \mathrm{N}, 65.312370^{\circ} \mathrm{E}$;

9. open tundra in the area of $68.121314^{\circ} \mathrm{N}, 65.165382^{\circ} \mathrm{E}$;

10. near the mouth of the Izyashor stream, $68.131620^{\circ} \mathrm{N}$, $65.165658^{\circ} \mathrm{E}$.

The studied area is located in the arctic tundra subzone. From the mouth of Kara, on the coast of the Kara sea, the most widespread are green moss and moss-lichen tundra. Different types of tundra are presented to the south of the shores of the Kara and its tributaries: shrubmoss spotted, shrub (dwarf birch - "yernik"), meadow tundra. In river valleys, on the banks of the streams shrub willow, meadow tundra is developed [Martynenko, 1999]. Butterflies were collected in the valley of Kara mainly in areas of the forb meadows, in a mosaic willow, dwarf birch shrub-sedge tundra. The butterflies in NyarmaYakha and Brusyyakha river valleys on the terrace above the floodplain and the placore were observed mainly in dwarf birch-Dryas dry lichen tundra. At the mouth of the Izyashor stream butterflies were observed on sites of meadow tundra and wet tundra with thickets of Arctic willow (Salix arctica) and the bistort (Polygonum bistorta). In the area of Verhnekarsky canyon imago recorded in moss-shrub tundra with the aspect of cotton grass (Eriophorum) and dwarf birch (Betula nana).

\section{Result}

Annotated list of species of Lepidoptera (Hesperioidea and Papilionoidea) of the river Kara basin contains information about the observation and collection of material, the quantity and biotopic preferences of species. Asterisk marks species mentioned for this 
localities for the first time here. We also confirm the distribution of all the species found in the upper flows of the Kara river in recent time [Tatarinov, Kulakova, 2017].

\section{Hesperiidae}

1. Pyrgus centaureae (Rambur, 1839)*. 6. The single specimen is found at the valley slope on the sites of the meadow tundra.

\section{Papilionidae}

2. Parnassius phoebus (Fabricius, 1793)*. 6. One of the most northern locality of the species in Europe. One male is discovered on 30 July, 2017 on the slope of the valley at the border of the forb meadow and willow shrubs.

\section{Pieridae}

3. Pieris bryoniae (Hübner, 1791)*. 2, 3, 4. On the banks of Kara it was noted in areas at the border of the forb meadow and willow shrubs.

4. Pontia callidice (Hübner, [1800]). 3. It was previously mentioned for Kara by N. Ya. Kuznetsov [1925]. One male observed on rocky dry place among lichen tundra.

5. Colias palaeno (Linnaeus, 1758)*. 1, 2, 3, 4, 5, 6, 7. The most widespread species in all points of observation. It inhabits various types of tundra.

6. Colias hecla Lefebvre, 1836*. 1, 2, 3, 5, 6. The widespread species found in nearly all localities in 2017. According to the field data, in 2017 , about $30 \%$ is dominated by females. Found mostly along forb meadow tundra in the river valleys, in dry Dryas and lichen tundra, avoiding wet, swampy areas.

\section{Satyridae}

(Nymphalinae)

7. Nymphalis xanthomelas (Esper, 1781). 1, 4. The species was mentioned for Kara by Collected single imagines relate to overwintering in adult stage individuals. In the Polar Ural it migrates from more southern regions through the forested river valleys [Tatarinov, Dolgin, 1999]. In Kara river basin it can have the stable populations which enrich regularly by fresh specimens [Tatarinov, Kulakova, 2017]. It was also observed as abundant in the valley of the Khanmey stream in the Polar Urals (fresh specimens collected by T.A. Galkina in July 2016), as well as overwintered adults in the Subpolar Urals in the floodplain of the river Lemva (materials of the A.V. Makarov's expedition in 2017).

8. Issoria eugenia (Eversmann, 1847)*. 5, 6. In the studied area it is rare, found in meadows in the valley of Kara and its tributaries.

9. Boloria eunomia (Esper, 1799)*. 1, 6. Rare, noted in dwarf birch and shrub-sedge tundra, wet tundra.

10. Boloria selene ([Denis et Schiffermuller, 1775])*. 2, 3, 10. Rare specis found in sedge and forb meadows in the tundra.

11. Boloria frigga (Becklin in Thunberg, 1791)*.1, 2, 3, 4, 5, 10. Dwarf birch and Dryas dry lichen tundra in the river valleys and on the floodplain terraces. Frequent.

12. Boloria improba (Butler, 1877). 2, 3, 5. It was previously mentioned for Kara without detailed data on the localities by N.Ya. Kuznetsov [1925]. Rare species found in dry mixed grassy, meadow tundra, rocky areas in the tundra.

13. Boloria chariclea (Schneider, 1794). 1, 7. It was previously mentioned for Kara without detailed data on the localities by N.Ya. Kuznetsov [1925]. On the banks of the rivers it inhabits the sedge and forb meadow tundra.

14. Boloria polaris (Boisduval, 1829). 2. It was previously found in the basin of Kara by N. Ya. Kuznetsov [1925]. 21 July 2017 found on rocky slopes of the floodplain terrace, close to snowfield at the mouth of the river Nyarma-Yakha.

15. Boloria alaskensis (Holland, 1900)*. 1, 2, 3, 4, 5, 7, 9, 10. The widespread species found in all localities in 2015 and 2017, in different tundra types.

\section{(Satyrinae)}

16. Coenonympha tullia (Müller, 1764)*. 4, 5, 7. It is frequent in dwarf birch, low shrub and wet tundra, mostly in moist areas in the river valleys.

17. Erebia euryale (Esper, 1805)*. 9, 10. In 2015 is frequent, but in 2017 single specimens were found in dwarf birch shrub tundra.

18. Erebia rossii (Curtis in Ross, 1834). 1, 2. It was previously observed in the Kara river basin by N.Ya. Kuznetsov [1925]. It inhabits forb meadow tundra in the river valley, drying up sedge swamps and among the low shrub tundra. Single individuals were seen on the sandy banks of rivers.

19. Erebia disa (Becklin in Thunberg, 1791)*. 1, 9. Some single specimens were found on the drying up sedge swamp.

20. Erebia fasciata (Butler, 1868). 6. It was previously observed in the Kara river basin by N.Ya. Kuznetsov [1925]. One male was noticed on the stony site in the Dryas and lichen tundra.

21. Oeneis melissa (Fabricius, 1775). 6. It was previously observed in the Kara river basin by N.Ya. Kuznetsov [1925]. One male was noticed on the stony site in the lichen tundra.

\section{Lycaenidae}

22. Plebeius optilete (Knoch, 1781)*. 1, 2, 3, 6, 7, 8, 9, 10. The abundant species found in almost all localities. It inhabits mainly areas of moss-shrub tundra sites, cotton grass and shrub bogs and banks of streams and lakes among the dwarf birch associations.

23. Agriades aquilo (Boisduval, 1832)*. 1, 2, 3, 5. In the Nyarma-Yakha river valley inhabits the terrace above the floodplain and placore in the low shrub, sedge, green moss and shrub, Dryas and lichen tundra. In the Brusyyakha valley it was noticed on the slopes with the forb meadow tundra.

24. Polyommatus eros (Ochseinheimer, 1808)*. 2. The species was found in 2 localities in the mouth of NyarmaYakha river in the dwarf birch and lochen tundra.

\section{Discussion}

24 butterfly species are found in the basin in the Kara basin by now, accounting for about $30 \%$ of the fauna of this group of the European North-East and $95 \%$ of the fauna of the Polar Urals. It should be noted that the index of species diversity is quite high for the area, and also promising its possible extension by species flying in the beginning of phenological summer ( 3 decade of June -1 decade of July) that is not covered by the last expeditionary studies. Despite the extreme climatic conditions of high latitudes, the level of species diversity is higher than in the similar latitude areas of the Murmansk region and the north of Fennoscandia. For example, in the north of 
the Kola Peninsula (68-69 degrees north latitude) in different types of tundra it can be found about 19 species of butterflies [Kozlov, Kullberg, 2008].

It is also important to take into consideration the ecological value of the study area to conservation of the arctic insectocenosis. Due to the almost complete absence of the human activity, the tundra ecosystems along the river Kara survived almost intact, apart from the processes of natural successional dynamics. In this regard, the relevant protection and study as the typical, model natural complex, in which many Lepidoptera species protected in Europe can be found nowadays. Thus, the indicator of the arctic tundra preservation can be the arctic Boloria species complex (B. improba "Endangered" in IUCN Red List status, $B$. polaris "Vulnerable", B. chariclea - "Near threatened") [van Swaay et al., 2010]. B. chariclea and B. improba are under protection in the Nenetsky Autonomous Okrug with the third (III) protection category [Red book of the Nenetsky Autonomous Okrug, 2006], and A. aquilo ("Least Concern" status in the Red list of the European butterflies) [van Swaay et al., 2010]. The latter species was observed to the south in the vicinity of Vorkuta, the Krasny Kamen station and to the north of the Harp station as quite numerous [data of A. Okulov, 2005; O.V. Zurilina, 2017]. It is also important to note the most Northern European finds of P. phoebus, I. eugenia included in the Red books of the Komi Republic [1999] and Yamalo-Nenetsky Autonomous Okrug [2010]. The single found specimen of E. fasciata, which is rare and sporadic species in the Polar Urals [Red book of the Komi Republic, 1999; Red Book of the YamaloNenetsky Autonomous Okrug, 2010], however, is not the most northern locality in Europe, because it has been found in our expedition to the south island of Novaya Zemlya archipelago in 2005.

Analysis of faunal composition of collected butterflies in the basin of the Kara in 2015 showed the predominance of the arctoboreal species complex and the almost complete absence of typical arctic species by the type of their distribution. So, the single specimen of circumpolar distribution butterflies was 1 female of $B$. chariclea. The predominance of the material was common species of the boreal forests and oligotrophic bog complexes in the forest zone (E. euryale, B. selene, $B$. frigga, $C$. palaeno, C. tullia). It was also previously shown that a half of Kara's butterfly fauna doesnot belong to the typical arctic zoogeographical complex [Tatarinov, Kulakova, 2017]. The results of this expedition, compared with the data of 1925 , allowed to hypothesize the elimination of arctic species from tundra communities of Kara, changing the boundaries of their ranges, and "borealizing" fauna and its general degradation. Thus, this trend correlates with the general process of the gradual advance of the southern border of distribution of the butterfly fauna to the North, which is the most obvious in recent years in various regions of Central Russia, and also in the middle Urals and which is connected with the global climate change [Settele et al., 2008] and the other factors. However, the results of the expedition of 2017 showed the high faunal heterogeneity and its diversity. This expedition confirmed all previous findings of the butterfly species, and also revealed new species (16 new for some localities), including the circumpolar, arctic species. However, it should be noticed that the number of taiga and oligotrophic bog preferring species in general is higher and they dominate in a variety of communities, while the typical arctic species are usually isolated and highly sthenotopic. A high degree of habitat preferences were noted for A. aquilo, B. improba, B. chariclea found only in 2-4 localities.

AKNOWLEDGEMENTS. It is necessary to express my deep gratitude to colleagues who organized the expeditions in difficult conditions at high latitudes - A.V. Makarov, T.V. Ariasova, Dr. I.A. Savinov, S.V. Rupasov (Moscow, Russia), as well as members of the expeditionary groups who carried out the field observations and collectings (V. Kuzmenko, A. Nosova, V. Krivtsova, V. Kaplan) and the O.V. Zurilina (Chelyabinsk, Russia), providing the materials from the Polar Urals.

\section{References}

Korshunov Yu.P. 2002. [Butterflies of the Northern Asia] Moscow: KMK Scientific Press. 424 pp. [in Russian]

Korshunov Yu.P., Gorbunov P.V. 1995. [Butterflies of the Asiatic part of Russia. Handbook]. Ekaterinburg: Izdatelstvo Uralskoto gosudarstvennogo universiteta. 202 pp. [in Russian]

Kozlov M.V., Kullberg J. 2008. Lepidoptera of tundra habitats of the northern Kola peninsula, Northwestern Russia // Entomol. Fennica. Vol.19. P.114-121.

Kuznetsov N.Ya. 1925. Some new Eastern and American elements in the fauna Lepidoptera of Polar Europa // Doklady AN SSSR. Ser.A. P.119-122.

Red book of the Nenetsky Autonomous Okrug. 2006. / Ed. by O.V. Lavrinenko, I.A. Lavrinenko. Naryan-Mar: GUP NAO “Nenetsky informatsionno-analitichesky tsentr". 450 pp. [in Russian]

Red book of the Komi Republic. Rare and threatened of extinction species of plants and animals. 1999. / Ed. by A.I. Taskaev. Moscow: Izdatelstvo DIK. 528 pp. [in Russian]

Red book of the Yamalo-Nenetsky Autonomous Okrug: animals, plants, mushrooms. 2010. / Ed. by S.N. Ektova, D.O. Zamyatin. Ekaterinburg: Izdatelstvo "Basko". 308 pp. [in Russian]

Lvovsky A.L., Morgun D.V. 2007. [Butterflies of the Eastern Europe]. Moscow: KMK Scientific Press. 443 pp. [in Russian].

Martynenko V.A. 1999. [Vegetation and flora] // Komi Republic forests. Moscow: Dizain. Informatsia. Kartografia. P.41-47 [in Russian].

Tatarinov A.G., Dolgin M.M. 1999. [Fauna of the European NorthEast. Butterflies]. Vol.VII. Part 1. Saint-Petersbourg: Nauka Publ. 182 pp. [in Russian]

Tatarinov A.G., Kulakova O.I. 2005. [Butterflies (Lepidoptera, Rhopalocera) of the Bolshezemelskaya tundra] // Evroasiatsky Entomol. Journ. Vol.4. No.4. P.331-337 [in Russian].

Tatarinov A.G., Kulakova O.I. 2007. [The local faunas of butterflies (Lepidoptera: Papilionoidea, Hesperioidea) of the European Russian North: the low flow of Khalmer-Yu river] // Invertebrates of the European Russian North-East Trudy Komi nauchnogo centra UrO RAN. Vol.183. Syktyvkar. P.256-265 [in Russian].

Tatarinov A.G., Kulakova O.I. 2017. [Local faunas of butterflies (Lepidoptera: Papilionoidea, Hesperioidea) in the European North of Russia: Head reaches of the Kara river] // Vestnik Instinuta biologii Komi nauchnogo tsentra Ural'skogo otdeleniya RAN. Vol.1. No.199. P.36-43 [in Russian].

Sedykh K.F. 1974. [Animals of the Komi ASSR. Invertebrates]. Syktyvkar. 192 pp. [in Russian] 
Settele J., Kudrna O., Harpke A., Kühn I., van Swaay C., Verovnik R., Warren M., Wiemers M., Hanspach J., Hickler Th., Kühn E., van Halder I., Veling K., Vliegenthart A., Wynhoff I. \& Schweiger O. 2008. Climate Risk Atlas of European Butterflies (PDF Download Available). Available from: https://www.researchgate.net/publication/222096076_Climate_Risk_Atlas_of_European_Butterflies [accessed Oct 06 2017].
Tatarinov A.G., Dolgin M.M.2001. [Species diversity of butterflies of the European Russian North East]. Saint-Petersbourg: Nauka. 244 pp. [in Russian]

van Swaay C., Cuttelod A., Collins S., Maes D., López Munguira M., Šašić M., Settele J., Verovnik R., Verstrael T., Warren M., Wiemers M. and Wynhof I. 2010. European Red List of Butterflies. Luxembourg: Publications Office of the European Union. 58 pp. 